\title{
Japanese and Indonesian Relative Clausa Patterns
}

\author{
Ngurah Indra Pradhana \\ Program Studi Sastra Jepang Universitas Udayana \\ Jalan Pulau Nias No. 13 Sanglah-Denpasar \\ $+62361224121$ \\ indra_pradana@unud.ac.id
}

\begin{abstract}
The object of study in this research is clause. This research is focused on the derivation of clauses known as relative clauses. In this study, it was examined about the differences and similarities in the formation patterns, meanings, and relation characteristics of clauses which are relatively good in two languages, namely between Japanese and Indonesian. The results of this research can be used in the teaching and learning process. As well as useful for readers and audiences who intend to pursue linguistics. The study begins by collecting data regarding the use of relative clauses to the research subject. The analytical method used in this research is the agih method. Based on the analysis that has been done, several conclusions can be drawn as follows. In Indonesian, a relative clause is indicated by the word "yang" as a conjunctive pronoun. Relative clauses can be used as an expansion technique. There is a slight difference in the formation of Relative Clauses in Indonesian and Japanese, namely, in Indonesian the relative clause can only consist of the word "yang" as a relative clause marker and a predicate which functions as a modifier which is then followed by a core sentence. Whereas in Japanese, a relative clause consists of a minimum of objects and a predicate as a modifier followed by a core sentence. Semantically, relative clauses are viewed from proportions formed by a predicate which states activities, processes, or circumstances. The characteristic of the relation in a relative clause is indicated by the word that comes after the noun.
\end{abstract}

Keywords: relative clauses, structure, meaning, characteristics of the relation

\section{Introduction}

Everything in this world can be visualized in the form of language. Language can be said to be the capital of all things in this world. For this reason, language needs to be learned. The science of language or the science that makes language the object of its study is called linguistics. The word linguistics comes from the Latin lingua which means "language".

Based on the object of study, linguistics can be divided into micro linguistics and macro linguistics. Micro linguistics directs its study to the internal structure of language. Micro linguistics includes phonology, morphology, syntax, semantics, lexicology. While macro linguistics studies language in relation to factors outside of language. Macrolinguistics includes several subdisciplines, among others: sociolinguistics, psycholinguistics, dialectology and others.
This research is categorized in micro linguistic analysis, namely syntax. Syntax comes from the Greek sun and tatein which means putting together words into groups of words or sentences (Chaer, 2003). The syntactic term in Japanese is called 統語論」 or "shintakusu"」

According to Verhaar (1999) syntax is a science that discusses the relationship between words in speech. The relationship between these words includes grammatical units which include phrases, clauses and sentences. The understanding of syntax from some of the opinions above can be concluded that syntax is a part of linguistics that examines the formation of structures in sentences. While semantics is a branch of linguistics that makes meaning as the object of study.

Koizumi (1993) explains that syntax is the science of language which studies the merging of words into language units. The combination of words has a permanent pattern and structure that does not change. 
Meanwhile, according to Kridalaksana (2008) syntax is the arrangement and relationship between words with words or larger units. The elements of language that are included in the scope of syntax are phrases, clauses and sentences.

In this study, the object of the study is the clause. A clause is a grammatical unit in the form of a group of words which at least consists of a subject and a predicate and has the potential to become a sentence (Kridalaksana, 1983). This research is focused on the derivative of the clause known as the relative clause. In this study, we will examine the differences and similarities in the pattern of relative clause formation in two languages, namely between Japanese and Indonesian.

A clause is a grammatical unit in the form of a group of words which at least consists of a subject and a predicate and has the potential to become a sentence (Kridalaksana, 2008). In more depth, the clause develops with the term relative clause. A relative clause is a clause that is inserted in a sentence to provide additional information or to limit the parent noun whose information has been previously stated.

In Indonesian, relative clauses are marked with the word "yang" as a connecting pronoun. A relative clause consists of two parts, namely a restrictive (limiting) relative clause and a nonrestrictive (not limiting) relative clause. The presence of a restrictive relative clause is considered optional and only in addition. A restrictive relative clause has a pronoun which functions as a conjunction. (Djadjasudarma, 1997)

In Japanese, the relative clause is known as 関 係 節 (kankeisetsu). Kankeisetsu or relative clauses are additional words that can be in the form of adjectives, nouns or other information, can also be additional phrases that function to expand sentences.
The results of this study can be used in the teaching and learning process in the classroom, both those who intend to learn Japanese and Indonesian. And useful for readers and audiences who intend to pursue the field of linguistics. The results of this study are projected to be published in national journals.

\section{METHOD}

The research model is a scientific way to obtain data with specific purposes and uses. The scientific method means that research activities are based on scientific characteristics, namely rational, empirical, and systematic. The systematics in this study consisted of three stages, including the data collection stage, the data analysis stage, and the presentation stage of the data analysis results.

\section{Method of collecting data}

This study aims to describe relative clauses in data sources such as newspapers, magazines, and other print media in Japanese and Indonesian. Therefore, the appropriate method used in this research is descriptive method, which is a method used to describe the facts of the findings collected and then analyzed to determine the location of the determining elements of their use and to describe the characteristics of the data as they are.

In relation to the method chosen, this study emphasizes the use of relative clauses by identifying, describing and analyzing existing data. The study begins by collecting data regarding the use of relative clauses to the research subject. The method of data collection was carried out by means of a literature study, namely collecting data through various written sources, both in Japanese and in Indonesian, containing relative clauses.

\section{Analysis Method}

The data that has been collected is then analyzed using the agih method (distributional method). The research 
targets of the agih method, such as words (denial words, prepositions, adverbs, etc.), syntactic functions (subjects, objects, predicates, etc.), clauses, word syllables, pitch, and others. (Sudaryanto, 1993: 16). It is very appropriate to use this method because it examines the clause.

\section{Method of Presentation of Analysis Results}

In the final stage, namely the stage of presenting the results of the analysis. The presentation stage is the researcher's effort to present in the form of a written "report" the things that have been produced from the analytical work, especially the rules (Sudaryanto, 1993: 7). The method of presenting the rule is known as the method of presenting the rule; which consists of two kinds, namely the informal and the formal. Informal presentation method is a formulation with ordinary words (a natural language) while formal presentation is a formulation with signs and symbols (an artificial language) (Sudaryanto, 1993: 144145). In this study, the results of the analysis will be presented using an informal method, namely explaining the data by discussing all the elements descriptively.

\section{RESULTS AND DISCUSSION}

This study describes the structure and meaning of relative clauses in both Japanese and Indonesian. Linguists argue that a relative clause is a bound clause that begins with the relative pronominal yang. For example, who is standing in the sentence standing in front of the house is my father. From this example, it can be seen that the bound clause that is standing cannot stand alone as a complete sentence, but can be said as a minor sentence with final intonation. Kridalaksana (2001) states that the attachment of these clauses to other clauses appears in compound sentences.

\section{Relative Clauses Based on Structure in Compound Sentences}

In terms of formation, relative clauses in Indonesian have the following order: relative clauses followed by core clauses. There is a uniqueness in terms of formation, that the Relative Clause can be done with the Expansion Technique. The following is an example of a compound sentence (1) containing a Relative Clause with an Expansion Technique by adding personal pronouns, for example in sentence (2):

(1) (yang sedang berdiri di depan rumah itu) adalah ayah saya.

'(who was standing in front of the house) was my father.'

(2) Laki-laki (yang sedang berdiri di depan rumah itu) adalah ayah saya.

'The man (who was standing in front of the house) was my father.'

The formation of the Relative Clause in Japanese is the same as the formation of the Relative Clause in Indonesian. The equation is that the relative clause can precede and can also be behind the main sentence. For example in sentence (3) below:

(3) 飲んだ薬を忘れた。 nonda kusuri wo wasureta.

'Forgetting the medicine that has been taken.'

From sentence (3), which is a Relative Clause is "drugs that have been taken". In Japanese language rules, the predicate function in the form of verbs and adjectives is always at the end of the sentence and will undergo conjugation that is adjusted to the needs of the meaning of the sentence. From sentence (3), the predicate is the word "wasureta/forgetting". The word comes from the word "wasureru/forget" then undergoes past conjugation so that it turns into "wasureta/forgetting".

Likewise in Indonesian, relative clauses in Japanese can also be done with the Expansion Technique, which is like the example in sentence (4).

(4) 昨日、木村さんは飲んだ薬を忘 
Kinou, Kimura san ha nonda kusuri wo wasureta.

'Yesterday, Mr. Kimura forgot the medicine he had taken.'

In the example sentence (4), it can be seen that there is an expansion by adding the temporal adverb kinou 'yesterday' and adding the subject of the perpetrator, namely "Mr. Kimura". It's just that there is a slight difference in the formation of Relative Clauses in Indonesian and Japanese, namely, in Indonesian a relative clause can only consist of the word "yang" as a marker of a relative clause and a predicate that functions as a modifier, followed by a core sentence. Whereas in Japanese, the relative clause consists of a minimum of an object and a predicate as a modifier after that it is followed by a core sentence. Core sentences in both Indonesian and Japanese can appear before or after relative clauses. Here's an example:

Indonesian sentences:

(5) Yang berdiri adalah paman saya

'The one standing is my uncle'

(6) Guru Bahasa Jepang adalah yang sedang makan.

'The Japanese teacher is the one eating.' Japanese Sentences:

(7)＼cjkstart森田さんは読んでいる人です。

Morida san ha yonde iru hito desu.

'Morida is the one who is reading.'

(8) 立っている人は私の友達です。

Tatteiru hito ha watashi no tomodachi desu. 'The person standing is my friend.'

From the example sentence above, it can be seen that a relative clause is a series of words consisting of a main word as a core constituent that can function as part of a noun phrase. The main word is "proleptic head" while the relative clause is the attribute. For example, in the example sentence (8), "The person standing is my friend." The sentence consists of a standing clause which is an attribute of a nominal phrase The person who stands with the house as the central element or "head".
Relative clauses are viewed semantically in compound sentences

Semantically, relative clauses are viewed from the proportions formed by a predicate which states activities, processes, or circumstances. The predicate in the relative clause functions as a modifier, it can be in the form of a verb or an adjective or in Japanese the two groups of words are known as yoogen. The hallmark of yoogen is a group of words that undergo conjugation. Here are some examples;

\section{Predicate stating activity}

（9）昨日の買った本は破れてしまい ました。

Kinou no katta hon ha yabureteshimaimashita.

'The book that was bought yesterday, accidentally torn.'

\section{Predicate denoting process}

(10) あの食べている人は私の友達で す。

Ano tabeteiru hito ha watashi no tomodachi desu.

'That person who is eating is my friend.'

\section{Predicate stating the situation}

(11) あそこに咲いている花はバラで す。

Asoko ni saiteiru hana ha bara desu.

'The flower that is blooming there is a rose'

\section{Relative Clauses Based on Relation Characteristics}

In Indonesian, the relative clause is still a debate whether it exists or not. This is because the relative clause markers in Indonesian are in the form of connecting words. The conjunction cannot occupy a function in a sentence. The word is used as a bridge between clauses in a sentence.

In Indonesian, there are various words used. One of them is as a characteristic of relations in the formation of relative clauses. Characteristics of relations as stated by Sudaryanto $(1983: 41)$ that 
relations mark the presence of language as an identity. So researching the relationships that exist in language is mandatory. Characteristics of the relation in the relative clause which is indicated by the word that is placed after the noun, such as the example sentence:

(12) Orang yang berlari itu adalah pacar saya.

The person running is my girlfriend.

\section{CONCLUSION}

Based on the analysis that has been done, some conclusions can be drawn as follows. In Indonesian, relative clauses are marked with the word "yang" as a connecting pronoun. According to Djajasudarma (1997:25), a relative clause consists of two parts, namely a restrictive (limiting) relative clause and a nonrestrictive (not limiting) relative clause. The presence of a restrictive relative clause is considered optional and only in addition. A restrictive relative clause has a pronoun which functions as a conjunction. In the process of forming a Relative Clause in Japanese has similarities with the formation of a Relative Clause in Indonesian. Relative Clause can be done with the Expansion Technique. It's just that there is a slight difference in the formation of Relative Clauses in Indonesian and Japanese, namely, in Indonesian a relative clause can only consist of the word "yang" as a marker of a relative clause and a predicate that functions as a modifier, followed by a core sentence. Whereas in Japanese, the relative clause consists of a minimum of an object and a predicate as a modifier after that it is followed by a core sentence. Core sentences in both Indonesian and Japanese can appear before or after relative clauses. In Japanese language rules, the predicate function in the form of verbs and adjectives is always at the end of the sentence and will undergo conjugation that is adjusted to the needs of the meaning of the sentence. Semantically, relative clauses are viewed from the proportions formed by a predicate which states activities, processes, or circumstances. The predicate in the relative clause functions as a modifier, it can be in the form of a verb or an adjective or in Japanese the two groups of words are known as yoogen. The hallmark of yoogen is a group of words that undergo conjugation. In Indonesian, there are various words used. One of them is as a characteristic of relations in the formation of relative clauses. Characteristics of the relation in the relative clause which is indicated by the word that comes after the noun.

\section{REFERENCES}

Agustina. 2007. "Klausa Relatif dalam Bahasa Indonesia: Sebuah Fenomena Kontroversial". Linguistik Indonesia. Tahun ke-25. Nomor 2.1

Chaer, A. 2003 . Linguistik Umum. Jakarta: Rineka Cipta.

Djajasudarma, Fatimah.1997. Analisis Bahasa Sintaksis dan Semantik. Bandung: Humaniora Press.

Isao, I. 2001. Atarashii Nihongogaku Nyuumon.Tokyo: Three A Network.

Koizumi, Tamotsu. 1993. Nihongo Kyooshi no Tame no Gengogaku Nyuumon. Tokyo: Taishukan Shoten

Kridalaksana, Harimurti. 2008. Kamus Linguistik. Edisi Keempat. Jakarta: PT Gramedia Pustaka Utama

Kuno Susumu. 1973. Nihon Bunpoo Kenkyuu.Tokyo : Taishukan.

Lyons, J.1995. Teori Linguistik Umum.Yogyakarta: UGM Press.

Mahsun. 2006. Metode Penelitian Bahasa: Tahapan Strategi, Metode, dan Tekniknya. Jakarta: PT. Raja Grafindo Persada

Nishida, Tatsuo. et. al.1986. Gengogaku o Manabu Hito no Tame ni. Tokyo : Sekai Shisooka 
Okutsu, Keiichiro. 1996. Seisei Nihongo Bunporon. Tokyo : Taishukan Shoten

Samsuri. 1987. Analisa Bahasa. Jakarta: Erlangga.

Shibatani Yukio. 1997. Nihongo no Bunseki. Taishukan Shoten.

Shibatani, Masayoshi. 1983. Gengo no Koozoo. Tokyo: Kuroshio Shuppan.
Sudaryanto. 1993. Metode dan Aneka Tehnik Analisis Bahasa (Pengantar Penelitian Wahana Kebudayaan secara Linguistik). Yogyakarta : Duta Wacana University Press.

Teramura, Hideo. 1988. Nihongo no Shintakusu to Imi II. Tokyo: Kuroshio Shuppan.

Verhaar, J.W.M. 1999. Pengantar Linguistik. Yogyakarta: Gadjah Mada. University Press. 